OPEN ACCESS

Edited by:

Rajesh Jha

University of Hawaii at Manoa,

United States

Reviewed by:

Aiwei Guo,

Southwest Forestry University, China Jerubella Abelilla,

DSM, Switzerland

*Correspondence:

Ines Andretta

ines.andretta@ufrgs.br

Specialty section:

This article was submitted to Animal Nutrition and Metabolism,

a section of the journal

Frontiers in Veterinary Science

Received: 28 June 2021 Accepted: 02 September 2021

Published: 11 October 2021

Citation:

Hickmann FMW, Andretta I, Létourneau-Montminy M-P, Remus A, Galli GM, Vittori J and Kipper M (2021) $\beta$-Mannanase Supplementation as an Eco-Friendly Feed Strategy to Reduce the Environmental Impacts of Pig and

Poultry Feeding Programs.

Front. Vet. Sci. 8:732253.

doi: 10.3389/fvets.2021.732253

\section{$\beta$-Mannanase Supplementation as an Eco-Friendly Feed Strategy to Reduce the Environmental Impacts of Pig and Poultry Feeding Programs}

\author{
Felipe M. W. Hickmann ${ }^{1}$, Ines Andretta ${ }^{1 *}$, Marie-Pierre Létourneau-Montminy ${ }^{2}$, \\ Aline Remus ${ }^{3}$, Gabriela M. Galli ${ }^{1}$, Juliano Vittori ${ }^{4}$ and Marcos Kipper ${ }^{4}$
}

${ }^{1}$ Departamento de Zootecnia, Universidade Federal do Rio Grande do Sul, Porto Alegre, Brazil, ${ }^{2}$ Département des Sciences Animales, Faculté des Sciences de l'Agriculture et de l'Alimentation, Université Laval, Québec, QC, Canada, ${ }^{3}$ Sherbrooke Research and Development Center, Agriculture and Agri-Food Canada, Sherbrooke, QC, Canada, ${ }^{4}$ Elanco Animal Health, São Paulo, Brazil

Little is still known about the environmental impacts of exogenous enzyme supplementation in pig and poultry feeding programs. Thus, this study aimed to assess the potential environmental impacts of producing feeds for pigs and broilers by simulating the effects of $\beta$-mannanase Hemice/l ${ }^{\mathrm{TM}} H T$ supplementation through energy savings during diet formulation. Life-cycle assessment standards were applied to simulate a cradle-to-feed mill gate scope. The functional units used were the production of $1 \mathrm{~kg}$ of the enzyme and $1 \mathrm{~kg}$ of feed at a feed mill gate located in Concórdia, Santa Catarina, Brazil. Climate change, eutrophication, and acidification were the chosen environmental impact categories. Energy savings through $\beta$-mannanase supplementation were assessed by different metabolizable energy (ME) matrices (45 or $90 \mathrm{kcal}$ of $\mathrm{ME} / \mathrm{kg}$ of feed) during diet formulation in different grain production scenarios (Southern and/or Central-West origin). A total of 28 feeds were formulated based on the nutritional requirements and feeding programs described in the Brazilian Tables for Poultry and Swine. The least-cost formulation method was used based on real price averages practiced in a local industry over 12 months. The production of $1 \mathrm{~kg}$ of $\beta$-mannanase was associated with the emission of $1,800 \mathrm{~g}$ of $\mathrm{CO}_{2}$-eq, $4.53 \mathrm{~g}$ of $\mathrm{PO}_{4}$-eq, and $7.89 \mathrm{~g}$ of $\mathrm{SO}_{2}$-eq. For pig feeds, $\beta$-mannanase supplementation mitigated both climate change and eutrophication impacts up to 8.5 and $1.4 \%$ (45 kcal of $\mathrm{ME} / \mathrm{kg}$ of feed) or up to 16.2 and $2.7 \%$ (90 kcal of ME/ $\mathrm{kg}$ of feed) compared to control diets formulated without the enzyme. For broiler feeds, these impacts were mitigated up to 5.6 and $1.1 \%$ (45 kcal of ME/ $\mathrm{kg}$ of feed), respectively. On the other hand, the effect of using $\beta$-mannanase on the acidification impact was not consistent among feeds/species. Overall, $\beta$-mannanase supplementation reduced the amount of soybean oil in feed formulas, which is associated with high environmental impacts. 
Consequently, the potential impacts of climate change and eutrophication associated with producing feeds for pigs and broilers were substantially mitigated. These results suggest that $\beta$-mannanase supplementation is an eco-friendly feed strategy to reduce the environmental impacts of pig and poultry feeding programs.

Keywords: swine, broiler, environment, feed, enzyme, climate change, sustainability, life-cycle assessment

\section{INTRODUCTION}

Pig and poultry feeding programs require a huge amount of feed resources, with several studies indicating feeding as a major source of environmental impact (1-3). A systematic review recently developed by Andretta et al. (4) on the use of life cycle analysis confirmed the importance of feeding processes as the largest source of environmental impact associated with pig and poultry production. In their review, the relative participation of feed production in the overall greenhouse gas emissions varied from 31 to $76 \%$ or 28 to $82 \%$ for the pig and poultry databases, respectively (4). Regardless of the exact amount of impact attributed to feeding, practically all studies indicated feeding as the most important environmental impact source. These results support the hypothesis that novel feeding strategies could be used as eco-friendly strategies to mitigate the environmental impacts of pig and poultry production.

The use of exogenous enzymes has been highlighted as a promising alternative to mitigate the environmental impacts of livestock $(5,6)$. Nonetheless, pigs and poultry lack some enzymes, such as $\beta$-mannanase, to completely digest $\beta$-mannans commonly present in a great variety of feedstuffs, including soybean, corn DDG, sunflower, copra, and palm kernel meal-based diets. This may reduce growth performance once $\beta$-mannans are associated with increased intestinal viscosity and decreased nutrient digestibility, following an inflammatory process initiated in response to the $\beta$-mannans presence (79). Hemicell ${ }^{\mathrm{TM}} H \mathrm{H}$ is a source of $\beta$-mannanase, an energysparing enzyme that hydrolyzes $\beta$-mannans, avoiding the inflammatory reaction (10). $\beta$-mannanase supplementation can then potentially improve the nutrient digestibility and growth performance of pigs and broilers. In addition, when an energy matrix is attributed to the enzyme during feed formulation, some resources are saved, leading to an increase in energyuse efficiency.

Despite the importance of both pig and poultry sectors in developing countries, most studies that assessed the environmental impacts of exogenous enzyme supplementation had been developed based on European and North American conditions, with limited applicability to other major pig and poultry production regions. In addition, little is still known

Abbreviations: $\mathrm{CO}_{2}$-eq, carbon dioxide equivalent; $\mathrm{CW}$, Central-West region; $\mathrm{CW}-\mathrm{CW}$, the scenario in which only grains from the Central-West region were used to produce the feed; $\mathrm{CW}-\mathrm{SO}$, the scenario in which soybeans from the Central-West region and corn from the Southern region were used to produce the feed; DE: digestible energy; LCA, life-cycle assessment; ME, metabolizable energy; $\mathrm{SO}_{2}$-eq, sulfur dioxide equivalent; $\mathrm{SO}$, Southern region; $\mathrm{SO}-\mathrm{SO}$, the scenario in which only grains from the Southern region were used to produce the feed; $\mathrm{PO}_{4}$-eq, phosphate equivalent. about the environmental impacts of using $\beta$-mannanase in feeding programs. Therefore, this study aimed to assess the potential environmental impacts of producing feeds for pigs and broilers by simulating the effects of $\beta$-mannanase Hemicell $^{\mathrm{TM}}$ HT supplementation through energy savings during diet formulation.

\section{MATERIALS AND METHODS}

Environmental impacts were assessed according to life-cycle assessment (LCA) standards based on four interrelated steps, described by Guinée (11) as (i) goal and scope definition, (ii) life cycle inventory, (iii) life cycle impact assessment, and (iv) interpretation of results. Brazil was chosen because it is a large producer and exporter of pork and chicken meat. For this study, in a cradle-to-feed mill gate scope, the major stages considered in the model were the production of $\beta$ mannanase Hemicell ${ }^{\mathrm{TM}} H T$, the production of feed ingredients from plant sources (corn and soybean meal), and the production of the other feed ingredients (including amino acids, limestone, dicalcium phosphate, salt, and vitamin-mineral premix). Drying and processing in the feed industry as well as transportation were also considered, as illustrated in Figure 1. The functional unit used to study the environmental cost of feedstuff (especially for enzyme or grain production) was $1 \mathrm{~kg}$ of each ingredient at the feed factory. The functional unit used to study potential environmental impacts associated with feeds was $1 \mathrm{~kg}$ of feed manufactured and ready to be delivered to the farm (at the feed mill gate). The animal phase was not included in the scope due to limitations in data availability, mainly on the impact of $\beta$-mannanase supplementation (e.g., enteric fermentation). In addition, previous evidence showed no differences in performance (i.e., feed efficiency and nutrient metabolism) when supplementing $\beta$-mannanase with an energy matrix attributed during diet formulation (12).

\section{Description of the Pig and Poultry Production Systems Evaluated}

An inventory for $\beta$-mannanase Hemicell ${ }^{\mathrm{TM}} H T$ production was developed using detailed information provided by the manufacturer company (Elanco Animal Health, Greenfield, IN, US). Energy requirements (electricity, heating, and cooling) and emissions of $\mathrm{CO}_{2}$ during enzyme production were adapted from Gilpin et al. (13). Simulations considered enzyme production in the industrial plant at Greenfield (Delphos, US), followed by road transportation using trucks and marine transportation using cargo ships until arriving at the feed factory in Brazil. 


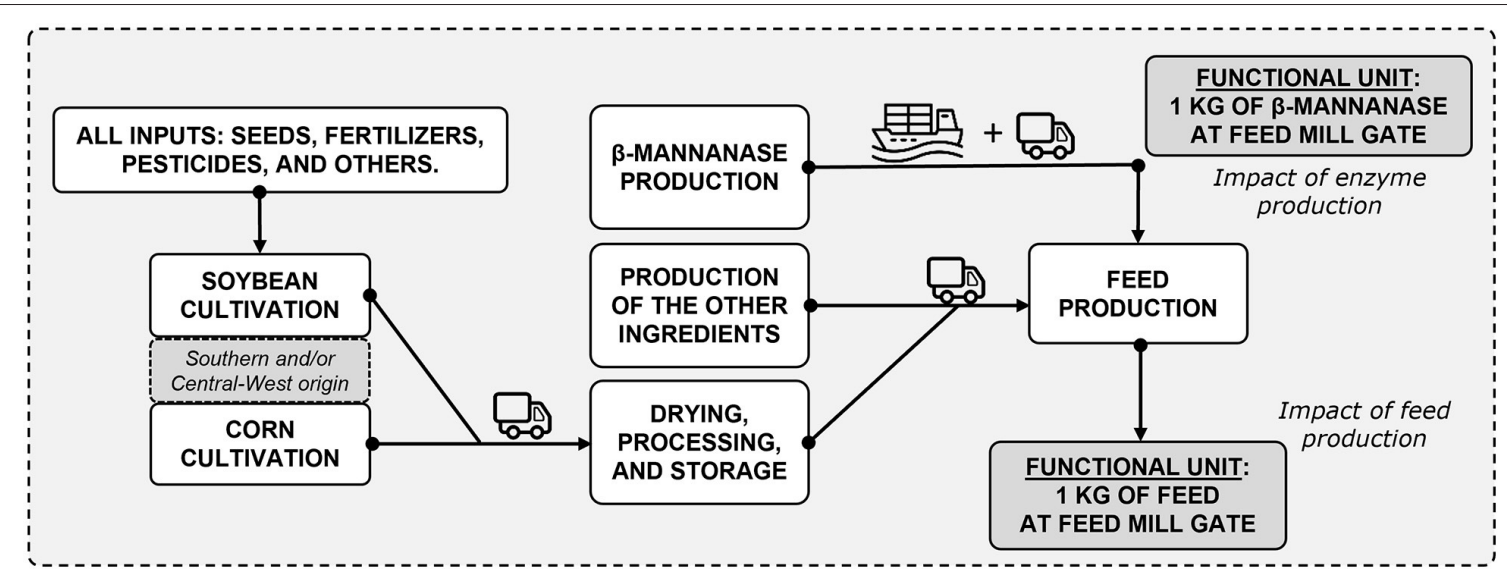

FIGURE 1 | Flowchart of the pig and poultry feeding programs being assessed through life-cycle assessment standards. Crop inputs, crop production, $\beta$-mannanase production, production of the other feed ingredients, drying, processing, storage, transportation, and feed production were the main processes considered, with system boundaries including all sub-processes.

TABLE 1 | Composition of nursery pig feeds ${ }^{\mathrm{a}}$.

\begin{tabular}{|c|c|c|c|c|c|c|}
\hline & \multicolumn{4}{|c|}{ Pre-starter } & \multicolumn{2}{|c|}{ Starter } \\
\hline & \multicolumn{2}{|c|}{ Complex } & \multicolumn{2}{|c|}{ Simple } & \multirow[b]{2}{*}{ Control } & \multirow[b]{2}{*}{$\beta$-mannanase } \\
\hline & Control & $\beta$-mannanase ${ }^{\mathrm{b}}$ & Control & $\beta$-mannanase & & \\
\hline \multicolumn{7}{|l|}{ Ingredient (as-fed basis), \% } \\
\hline Corn & 57.08 & 58.25 & 54.30 & 55.47 & 55.08 & 56.25 \\
\hline Soybean meal & 12.00 & 11.88 & 25.00 & 24.88 & 37.87 & 37.75 \\
\hline Soybean oil & 1.61 & 0.52 & 2.52 & 1.44 & 3.35 & 2.27 \\
\hline Meat and bone meal & 5.00 & 5.00 & 5.00 & 5.00 & - & - \\
\hline Soybean isolate protein & 8.13 & 8.13 & 4.30 & 4.30 & - & - \\
\hline Spray-dried plasma & 5.00 & 5.00 & 2.50 & 2.50 & - & - \\
\hline Whey & 10.00 & 10.00 & 5.00 & 5.00 & - & - \\
\hline L-lysine HCL & 0.11 & 0.11 & 0.17 & 0.17 & 0.29 & 0.29 \\
\hline DL-methionine & 0.10 & 0.10 & 0.11 & 0.11 & 0.13 & 0.13 \\
\hline L-threonine & 0.05 & 0.05 & 0.09 & 0.09 & 0.12 & 0.12 \\
\hline L-valine & 0.02 & 0.02 & 0.02 & 0.02 & 0.05 & 0.05 \\
\hline Salt & 0.22 & 0.22 & 0.21 & 0.21 & 0.19 & 0.19 \\
\hline Limestone & 0.41 & 0.41 & 0.42 & 0.42 & 1.05 & 1.05 \\
\hline Dicalcium phosphate & - & - & - & - & 1.13 & 1.13 \\
\hline Vitamin-mineral premix & 0.50 & 0.50 & 0.50 & 0.50 & 0.50 & 0.50 \\
\hline$\beta$-mannanase & - & 0.03 & - & 0.03 & - & 0.03 \\
\hline \multicolumn{7}{|c|}{ Calculated chemical composition ${ }^{c}$} \\
\hline Crude protein, \% & 23.81 & 23.81 & 24.08 & 24.08 & 21.88 & 21.88 \\
\hline SID lysine, \% & 1.35 & 1.35 & 1.35 & 1.35 & 1.28 & 1.28 \\
\hline Metabolizable energy, kcal/kg & 3,375 & 3,375 & 3,375 & 3,375 & 3,350 & 3,350 \\
\hline Digestible phosphorus, \% & 0.53 & 0.53 & 0.51 & 0.51 & 0.45 & 0.45 \\
\hline
\end{tabular}

a Pre-starter and starter feeds were formulated based on animals with 33-42 and 49-63 days of age, respectively, with 10.8 and $22.5 \mathrm{~kg}$ of body weight on average, respectively.

b $90 \mathrm{kcal}$ of metabolizable energy/kg of feed was the energy matrix attributed to the enzyme during diet formulation of nursery piglet feeds.

${ }^{c}$ Values were estimated considering the Brazilian Tables for Poultry and Swine (22).

d Standardized ileal digestible.

All other simulations were developed considering a feed mill located in Concórdia (Santa Catarina, Brazil) since it represents a traditional pig and poultry producing region in Southern
Brazil. Grain production was independently characterized in both Central-West (CW) and Southern (SO) regions in Brazil, as described by Andretta et al. (14). Crop farm locations were 
TABLE 2 | Composition of growing pig feeds ${ }^{a}$.

\begin{tabular}{|c|c|c|c|c|c|c|}
\hline & \multicolumn{3}{|c|}{ Growing I } & \multicolumn{3}{|c|}{ Growing II } \\
\hline & \multirow[t]{2}{*}{ Control } & \multicolumn{2}{|c|}{$\beta$-mannanase ${ }^{b}$} & \multirow[t]{2}{*}{ Control } & \multicolumn{2}{|c|}{$\beta$-mannanase } \\
\hline & & 45 kcal & 90 kcal & & 45 kcal & 90 kcal \\
\hline \multicolumn{7}{|l|}{ Ingredient (as-fed basis), \% } \\
\hline Corn & 68.60 & 69.59 & 70.63 & 73.69 & 74.67 & 75.72 \\
\hline Soybean meal & 23.43 & 23.31 & 23.19 & 19.73 & 19.61 & 19.49 \\
\hline Soybean oil & 2.22 & 1.32 & 0.41 & 1.89 & 1.00 & 0.08 \\
\hline Meat and bone meal & 3.35 & 3.34 & 3.33 & 2.39 & 2.38 & 2.37 \\
\hline L-lysine HCL & 0.49 & 0.49 & 0.49 & 0.46 & 0.46 & 0.46 \\
\hline DL-methionine & 0.19 & 0.19 & 0.19 & 0.15 & 0.15 & 0.15 \\
\hline L-threonine & 0.19 & 0.19 & 0.19 & 0.17 & 0.17 & 0.16 \\
\hline L-tryptophane & 0.06 & 0.06 & 0.06 & 0.05 & 0.05 & 0.05 \\
\hline L-valine & 0.07 & 0.07 & 0.07 & 0.06 & 0.05 & 0.05 \\
\hline Salt & 0.39 & 0.39 & 0.39 & 0.38 & 0.38 & 0.38 \\
\hline Limestone & 0.51 & 0.52 & 0.52 & 0.54 & 0.54 & 0.55 \\
\hline Vitamin-mineral premix & 0.50 & 0.50 & 0.50 & 0.50 & 0.50 & 0.50 \\
\hline Phytase & 0.01 & 0.01 & 0.01 & 0.01 & 0.01 & 0.01 \\
\hline$\beta$-mannanase & - & 0.03 & 0.03 & - & 0.03 & 0.03 \\
\hline \multicolumn{7}{|c|}{ Calculated chemical composition ${ }^{c}$} \\
\hline Crude protein, \% & 18.31 & 18.33 & 18.35 & 16.51 & 16.53 & 16.56 \\
\hline SIDd lysine, \% & 1.16 & 1.16 & 1.16 & 1.03 & 1.03 & 1.03 \\
\hline Metabolizable energy, kcal/kg & 3,350 & 3,350 & 3,350 & 3,350 & 3,350 & 3,350 \\
\hline Digestible phosphorus, \% & 0.38 & 0.38 & 0.38 & 0.33 & 0.33 & 0.33 \\
\hline
\end{tabular}

chosen based on rankings of the largest corn- and soybeanproducing municipalities within each region (15). Agricultural practices for grain production and the models used to calculate their emissions were adapted from Alvarenga (16), Alvarenga et al. (17), and Prudêncio da Silva et al. (18). The land transformation was estimated based on the data provided by Alvarenga (16), following the methodology described by Prudêncio da Silva et al. (18). Grain yield data were obtained from the Brazilian Institute of Geography and Statistics (15) for each municipality.

As pointed out by Prudêncio da Silva et al. (18), the environmental footprint of grain production depends on the Brazilian region being considered for crop cultivation. Thus, three geographic scenarios were simulated based on different crop cultivation locations: $\mathrm{CW}-\mathrm{CW}$, in which only grains from CW were used to produce feeds; CW-SO, in which soybean from CW and corn from SO were used to produce feeds; and $\mathrm{SO}-\mathrm{SO}$, in which only grains from SO were used to produce feeds. These scenarios differed in terms of road transportation distances, agricultural practices, and deforestation impact on recently opened agricultural frontiers (deforestation was assumed for the CW region but not included for the characterization of production in the SO region). Information from the Ecoinvent database (v. 3.0, Swiss Center for Life Cycle Inventories,
Dübendorf, Switzerland) was used to characterize soybean oil production. A process with solvent was applied for obtaining the product, with no geographical scenarios considered for oil production.

The impact of phytase supplementation was simulated considering the information provided by Nielsen et al. (5). The scope of synthetic amino acid production was adapted from Mosnier et al. (19), distinguishing amino acids produced by chemical synthesis (DL-methionine) from those produced by fermentation (L-lysine, L-threonine, L-tryptophane, and Lvaline). All other feed ingredients were based on available databases. The Ecoinvent database (v. 3.0, Swiss Center for Life Cycle Inventories, Dübendorf, Switzerland) was used to characterize the production of meat and bone meal, sodium chloride, and limestone. The environmental impacts of vitaminmineral trace elements were assumed to be equal to those of limestone. On the other hand, the environmental impacts of soybean protein isolate and whey were based on the AgriFootPrint database (v. 5.0, Blonk Consultants, Gouda, The Netherlands).

Grain processing and storage conditions were adapted from previous reports $(20,21)$. Transportation of grains (from the farm to the feed factory), other ingredients (from the industry to the feed factory), and feeds (from the feed factory to the 
TABLE 3 | Composition of finishing pig feeds ${ }^{a}$.

\begin{tabular}{|c|c|c|c|c|c|c|}
\hline & \multicolumn{3}{|c|}{ Finishing I } & \multicolumn{3}{|c|}{ Finishing II } \\
\hline & \multirow[t]{2}{*}{ Control } & \multicolumn{2}{|c|}{$\beta$-mannanase ${ }^{b}$} & \multirow[t]{2}{*}{ Control } & \multicolumn{2}{|c|}{$\beta$-mannanase } \\
\hline & & 45 kcal & $90 \mathrm{kcal}$ & & $45 \mathrm{kcal}$ & $90 \mathrm{kcal}$ \\
\hline \multicolumn{7}{|l|}{ Ingredient (as-fed basis), \% } \\
\hline Corn & 78.98 & 79.97 & 78.66 & 84.68 & 85.67 & 84.61 \\
\hline Soybean meal & 15.56 & 15.45 & 17.51 & 10.76 & 10.64 & 11.58 \\
\hline Soybean oil & 1.60 & 0.71 & - & 1.33 & 0.43 & - \\
\hline Meat and bone meal & 1.65 & 1.64 & 1.58 & 1.17 & 1.16 & 1.14 \\
\hline L-lysine HCL & 0.43 & 0.43 & 0.37 & 0.39 & 0.39 & 0.36 \\
\hline DL-methionine & 0.12 & 0.12 & 0.10 & 0.07 & 0.07 & 0.06 \\
\hline L-threonine & 0.14 & 0.14 & 0.11 & 0.10 & 0.10 & 0.09 \\
\hline L-tryptophane & 0.05 & 0.05 & 0.04 & 0.04 & 0.04 & 0.04 \\
\hline L-valine & 0.04 & 0.04 & 0.00 & 0.02 & 0.02 & 0.00 \\
\hline Salt & 0.36 & 0.36 & 0.36 & 0.35 & 0.35 & 0.35 \\
\hline Limestone & 0.57 & 0.57 & 0.74 & 0.59 & 0.59 & 1.23 \\
\hline Vitamin-mineral premix & 0.50 & 0.50 & 0.50 & 0.50 & 0.50 & 0.50 \\
\hline Phytase & 0.01 & 0.01 & 0.01 & 0.01 & 0.01 & 0.01 \\
\hline$\beta$-mannanase & - & 0.03 & 0.03 & - & 0.03 & 0.03 \\
\hline \multicolumn{7}{|c|}{ Calculated chemical composition $^{c}$} \\
\hline Crude protein, \% & 14.62 & 14.65 & 15.34 & 12.58 & 12.60 & 12.88 \\
\hline SID $^{d}$ lysine, \% & 0.90 & 0.90 & 0.90 & 0.75 & 0.75 & 0.75 \\
\hline Metabolizable energy, kcal/kg & 3,350 & 3,350 & 3,350 & 3,350 & 3,350 & 3,350 \\
\hline Digestible phosphorus, \% & 0.28 & 0.28 & 0.28 & 0.25 & 0.25 & 0.25 \\
\hline
\end{tabular}

pig farm) were assumed to have been done by truck, with the exception of enzymes that also included marine transportation. The Google Earth software (Google Inc., Mountain View, CA) was used to estimate transportation distances. Information from the Agri-footprint database (v. 5, Blonk Consultants, Gouda, The Netherlands) was used to simulate the impact of transportation.

\section{Feeding Practices}

Ingredients commonly used in Brazil were used to formulate feeds. Soybean meal was the major protein source, combined with corn and refined soybean oil as the major energy suppliers. A total of 28 feeds (Tables 1-4) were formulated based on the nutritional requirements and feeding programs described in the Brazilian Tables for Poultry and Swine (22). For pigs, pre-starter, starter, growing I, growing II, finishing I, and finishing II feeds were formulated based on animals with 33-42, 49-63, 70-84, 91$105,112-133$, and 140-161 days of age, respectively, and 10.8, $22.5,40,60,85$, and $112.5 \mathrm{~kg}$ of body weight, respectively. For broilers, starter I, starter II, growing I, growing II, and finishing feeds were formulated based on animals with 1-7, 8-21, 22-33, 34-42, and 43-46 days of age, respectively, and 0.14, 0.59, 1.65, 2.78 , and $3.48 \mathrm{~kg}$ of body weight, respectively. These feeds were formulated considering animals for slaughter only (excluding breeding animals) once they represent most of the feed produced in pig and poultry feeding programs, with complex and simple formulas being simulated for nursery pigs.

During diet formulation, the replacement of soybean oil was performed automatically by the formulation software (Formula 2000, Optimal Informatica, Campinas, Brazil). The least-cost formulation method was used considering real price averages practiced in a local industry over 12 months. The nutritional composition of the ingredients was obtained from the Brazilian Tables for Poultry and Swine (22). The metabolizable energy (ME) matrix of $\beta$-mannanase was chosen based on the most common values applied to the Brazilian industry (45 or $90 \mathrm{kcal}$ of $\mathrm{ME} / \mathrm{kg}$ of feed, depending on the species and rearing phase). Both matrices were simulated for growing-finishing pigs. While $45 \mathrm{kcal}$ of $\mathrm{ME} / \mathrm{kg}$ of feed was the energy matrix simulated for broilers, $90 \mathrm{kcal}$ of $\mathrm{ME} / \mathrm{kg}$ of feed was the energy matrix simulated for nursery pigs.

\section{Modeling Environmental Impacts}

Inputs and outputs were defined for each step of the life cycle and organized in a model using the SimaPro software (v. 9.1.1.1, PRE-Consultants, Amersfoort, The Netherlands). Environmental impacts related to capital assets (machinery, equipment, and buildings) were not considered in the model. The allocation of environmental burdens to by-products was based on economic criteria. The functional units considered were $1 \mathrm{~kg}$ of the enzyme 
TABLE 4 | Composition of broiler feeds ${ }^{a}$.

\begin{tabular}{|c|c|c|c|c|c|c|c|c|c|c|}
\hline & \multicolumn{4}{|c|}{ Starter } & \multicolumn{4}{|c|}{ Growing } & \multicolumn{2}{|c|}{ Finishing } \\
\hline & \multicolumn{2}{|c|}{$\mathbf{I}$} & \multicolumn{2}{|c|}{ II } & \multicolumn{2}{|c|}{$\mathbf{I}$} & \multicolumn{2}{|c|}{ II } & \multirow[b]{2}{*}{ Control } & \multirow[b]{2}{*}{$\beta \mathbf{M}$} \\
\hline & Control & $\beta \mathbf{M}^{\mathrm{b}}$ & Control & $\beta \mathbf{M}$ & Control & $\beta \mathbf{M}$ & Control & $\beta \mathrm{M}$ & & \\
\hline \multicolumn{11}{|l|}{ Ingredient (as-fed basis), \% } \\
\hline Corn & 43.59 & 44.54 & 45.38 & 46.32 & 50.52 & 51.44 & 59.20 & 60.12 & 63.80 & 64.73 \\
\hline Soybean meal & 46.11 & 45.96 & 43.60 & 43.46 & 38.02 & 37.90 & 30.87 & 30.76 & 26.69 & 26.57 \\
\hline Soybean oil & 5.50 & 4.66 & 6.60 & 5.76 & 7.13 & 6.30 & 6.24 & 5.40 & 6.13 & 5.30 \\
\hline L-lysine HCL & 0.22 & 0.22 & 0.22 & 0.23 & 0.35 & 0.35 & 0.34 & 0.34 & 0.34 & 0.34 \\
\hline DL-methionine & 0.41 & 0.41 & 0.39 & 0.39 & 0.38 & 0.38 & 0.31 & 0.30 & 0.26 & 0.26 \\
\hline L-threonine & 0.07 & 0.07 & 0.06 & 0.06 & 0.09 & 0.09 & 0.06 & 0.06 & 0.05 & 0.04 \\
\hline L-valine & 0.02 & 0.02 & 0.02 & 0.02 & 0.05 & 0.05 & 0.04 & 0.04 & 0.03 & 0.03 \\
\hline Salt & 0.22 & 0.22 & 0.21 & 0.21 & 0.19 & 0.19 & 0.17 & 0.17 & 0.16 & 0.16 \\
\hline Limestone & 1.07 & 1.07 & 0.96 & 0.97 & 0.91 & 0.92 & 0.76 & 0.76 & 0.69 & 0.69 \\
\hline Dicalcium phosphate & 1.84 & 1.84 & 1.61 & 1.61 & 1.41 & 1.41 & 1.07 & 1.07 & 0.92 & 0.91 \\
\hline Sodium bicarbonate & 0.45 & 0.45 & 0.45 & 0.45 & 0.44 & 0.44 & 0.44 & 0.44 & 0.44 & 0.44 \\
\hline Vitamin-mineral premix & 0.50 & 0.50 & 0.50 & 0.50 & 0.50 & 0.50 & 0.50 & 0.50 & 0.50 & 0.50 \\
\hline$\beta$-mannanase & - & 0.03 & - & 0.03 & - & 0.03 & - & 0.03 & - & 0.03 \\
\hline \multicolumn{11}{|c|}{ Calculated chemical composition ${ }^{c}$} \\
\hline Crude protein, \% & 24.56 & 24.57 & 23.56 & 23.57 & 21.55 & 21.57 & 18.95 & 18.97 & 17.39 & 17.41 \\
\hline SID ${ }^{d}$ lysine, \% & 1.36 & 1.36 & 1.31 & 1.31 & 1.24 & 1.24 & 1.07 & 1.07 & 0.97 & 0.97 \\
\hline Metabolizable energy, kcal/kg & 3,000 & 3,000 & 3,100 & 3,100 & 3,200 & 3,200 & 3,250 & 3,250 & 3,300 & 3,300 \\
\hline Digestible phosphorus, \% & 0.48 & 0.48 & 0.43 & 0.43 & 0.38 & 0.38 & 0.31 & 0.31 & 0.27 & 0.27 \\
\hline
\end{tabular}

a Starter I, starter II, growing I, growing II, and finishing feeds were formulated based on animals with 1-7, 8-21, 22-33, 34-42, and 43-46 days of age, respectively, and 0.14, 0.59, $1.65,2.78$, and $3.48 \mathrm{~kg}$ of body weight, respectively.

${ }^{b} \beta$-mannanase supplementation, $45 \mathrm{kcal}$ of metabolizable energy/kg of feed was the energy matrix attributed to the enzyme during diet formulation of broiler feeds.

${ }^{c}$ Values were estimated considering the Brazilian Tables for Poultry and Swine (22).

d Standardized ileal digestible.

at the feed mill gate to account for the environmental impacts associated with $\beta$-mannanase supplementation and $1 \mathrm{~kg}$ of feed at the feed mill gate to evaluate the impact of feed production and the grain production scenarios.

Climate change, eutrophication, and acidification were the chosen environmental impact categories, the most common impact categories used to assess the environmental impacts of pig and poultry production (4). Results were obtained for each environmental impact category, stating the resources used in each production system and the aggregate emissions of each substance with the respective characterization factor. The CMLIA baseline method was used through the SimaPro software to calculate the environmental impacts $\left(\mathrm{CO}_{2}\right.$-eq, $\mathrm{PO}_{4}$-eq, and $\mathrm{SO}_{2}$-eq). Changes in potential environmental impacts associated with $\beta$-mannanase supplementation were estimated considering the total amount of feed used to raise a pig or a broiler (from hatch/weaning until slaughter, excluding feeds for breeders). For this simulation, feed intake was estimated using the Brazilian Tables for Poultry and Swine (22).

\section{Simulating Another Formulation Strategy}

Data obtained from a previous study (12) was also simulated to consider a different energy matrix released through $\beta$ mannanase supplementation. Even though formulas had the same ingredient base (corn and soybean meal), the formulation procedure differs from the one described in this study. Lv et al. (12) did not use the least-cost formulation method to formulate diets, with $150 \mathrm{kcal}$ of digestible energy (DE)/ kg of feed being released in $\beta$-mannanase supplemented diets.

\section{Simulating the Environmental Impacts Associated With Energy Reduction}

Under Brazilian pig and poultry production conditions, the main change in ingredients after the inclusion of $\beta$-mannanase during diet formulation is the reduction of soybean oil content. The association between the reduction of soybean oil content in feed formulas and the estimated mitigation of environmental impacts was evaluated using regression analysis. The significance $(P<$ 0.05 ) of each equation term was evaluated before interpretation. Since species was not significant, one regression was created for both pigs and broilers. Analyses were performed using the Minitab 20.2.0 software (23).

Another simulation was performed to estimate the minimum amount of energy matrix necessary to mitigate the environmental cost of producing and transporting the enzyme. In this case, due to changes in diet formulation with $\beta$-mannanase supplementation, the soybean oil impact was fully replaced by the impact of corn in the simulation. ME values for soybean oil and corn were those proposed in the Brazilian Tables for Poultry and Swine (22). Information from the Ecoinvent 
TABLE 5 | Potential environmental impacts of control feeds ${ }^{\mathrm{a}}(1 \mathrm{~kg}$ at feed mill gate, formulated without $\beta$-mannanase) for nursery piglets in different grain production scenarios.

\begin{tabular}{|c|c|c|c|}
\hline & \multicolumn{2}{|c|}{ Pre-Starter } & \multirow[t]{2}{*}{ Starter } \\
\hline & Complex & Simple & \\
\hline \multicolumn{4}{|l|}{ SO-SO scenario ${ }^{b}$} \\
\hline Climate change, $\mathrm{g} \mathrm{CO}_{2}$-eq & 1,266 & 994 & 695 \\
\hline Eutrophication, $\mathrm{g} \mathrm{PO}_{4}$-eq & 4.08 & 4.38 & 4.66 \\
\hline Acidification, $\mathrm{g} \mathrm{SO}_{2}$-eq & 7.79 & 7.14 & 6.78 \\
\hline \multicolumn{4}{|l|}{ CW-SO scenario ${ }^{C}$} \\
\hline Climate change, $\mathrm{g} \mathrm{CO}_{2}$-eq & 1,336 & 1,138 & 914 \\
\hline Eutrophication, $\mathrm{g} \mathrm{PO}_{4}$-eq & 4.06 & 4.34 & 4.59 \\
\hline Acidification, $\mathrm{g} \mathrm{SO}_{2}$-eq & 8.13 & 7.84 & 7.85 \\
\hline \multicolumn{4}{|l|}{ CW-CW scenario ${ }^{d}$} \\
\hline Climate change, $\mathrm{g} \mathrm{CO}_{2}-\mathrm{eq}$ & 1,398 & 1,198 & 974 \\
\hline Eutrophication, $\mathrm{g} \mathrm{PO}_{4}$-eq & 4.12 & 4.39 & 4.65 \\
\hline Acidification, $\mathrm{g} \mathrm{SO}_{2}$-eq & 7.53 & 7.27 & 7.26 \\
\hline
\end{tabular}

a Pre-starter and starter feeds were formulated based on animals with 33-42 and 49-63 days of age, respectively, with 10.8 and $22.5 \mathrm{~kg}$ of body weight on average, respectively. bSO-SO scenario: Soybean and corn produced in Southern Brazil.

${ }^{C} \mathrm{CW}$-SO scenario: Soybean produced in Central-West Brazil and corn produced in Southern Brazil.

${ }^{d}$ CW-CW scenario: Soybean and corn produced in Central-West Brazil.

database (v. 3.0, Swiss Center for Life Cycle Inventories, Dübendorf, Switzerland) was used to characterize the soybean oil production. The environmental impact of oil reduction was estimated considering other references to include variability in the simulations (AgriFootPrint v. 5.0, Blonk Consultants, Gouda, The Netherlands), all based on Brazilian production scenarios.

\section{RESULTS}

The production of corn (functional unit: $1 \mathrm{~kg}$ at the feed mill gate) in the Southern region led to the emission of $491 \mathrm{~g}$ of $\mathrm{CO}_{2}$ eq, $3.78 \mathrm{~g}$ of $\mathrm{PO}_{4}$-eq, and $9.98 \mathrm{~g}$ of $\mathrm{SO}_{2}$-eq. For the Central-West region, corn showed a higher impact concerning climate change $\left(601 \mathrm{~g}\right.$ of $\mathrm{CO}_{2}$-eq; $\left.+22 \%\right)$ and eutrophication $\left(3.88 \mathrm{~g}\right.$ of $\mathrm{PO}_{4}$-eq; $+3 \%)$ but a lower impact concerning acidification $\left(8.92 \mathrm{~g}\right.$ of $\mathrm{PO}_{4}{ }^{-}$ eq; $-11 \%)$ compared to the Southern region. The production of soybean meal ( $1 \mathrm{~kg}$ at the feed mill gate) in the Southern region was associated with the emission of $533 \mathrm{~g}$ of $\mathrm{CO}_{2}$-eq, $5.82 \mathrm{~g}$ of $\mathrm{PO}_{4}$-eq, and $2.62 \mathrm{~g}$ of $\mathrm{SO}_{2}$-eq. In comparison with the Southern region, soybean meal from the Central-West region showed a higher impact concerning climate change $\left(1,110 \mathrm{~g}\right.$ of $\mathrm{CO}_{2}$ eq; $+108 \%$ ) and acidification $\left(5.43 \mathrm{~g}\right.$ of $\mathrm{SO}_{2}$-eq; $\left.+107 \%\right)$ but a lower impact concerning eutrophication (5.64 $\mathrm{g}$ of $\mathrm{PO}_{4}$-eq;-3\%). These differences among ingredient origins are highlighted in the impacts of producing complete feed formulas (functional unit: $1 \mathrm{~kg}$ at the feed mill gate) for pigs and broilers, which are presented in Tables $5-7$.

The production of $\beta$-mannanase ( $1 \mathrm{~kg}$ at the feed mill gate) was associated with the emission of $1,800 \mathrm{~g}$ of $\mathrm{CO}_{2}$-eq, $4.53 \mathrm{~g}$ of $\mathrm{PO}_{4}$-eq, and $7.89 \mathrm{~g}$ of $\mathrm{SO}_{2}$-eq. When feeds were reformulated
TABLE 6 | Potential environmental impacts of control feeds ${ }^{\mathrm{a}}(1 \mathrm{~kg}$ at feed mill gate, formulated without $\beta$-mannanase) for growing-finishing pigs in different grain production scenarios.

\begin{tabular}{|c|c|c|c|c|}
\hline & \multicolumn{2}{|c|}{ Growing } & \multicolumn{2}{|c|}{ Finishing } \\
\hline & I & II & I & II \\
\hline \multicolumn{5}{|l|}{ SO-SO scenario ${ }^{b}$} \\
\hline Climate change, $\mathrm{g} \mathrm{CO}_{2}$-eq & 633 & 614 & 596 & 577 \\
\hline Eutrophication, $\mathrm{g} \mathrm{PO}_{4}$-eq & 4.33 & 4.25 & 4.15 & 4.03 \\
\hline Acidification, $\mathrm{g} \mathrm{SO}_{2}$-eq & 7.81 & 8.18 & 8.55 & 8.95 \\
\hline \multicolumn{5}{|l|}{ CW-SO scenario ${ }^{C}$} \\
\hline Climate change, $\mathrm{g} \mathrm{CO}_{2}$-eq & 768 & 728 & 686 & 639 \\
\hline Eutrophication, $\mathrm{g} \mathrm{PO}_{4}$-eq & 4.29 & 4.21 & 4.12 & 4.01 \\
\hline Acidification, $\mathrm{g} \mathrm{SO}_{2}$-eq & 8.47 & 8.73 & 8.99 & 9.25 \\
\hline \multicolumn{5}{|l|}{ CW-CW scenario ${ }^{d}$} \\
\hline Climate change, $\mathrm{g} \mathrm{CO}_{2}$-eq & 844 & 809 & 773 & 732 \\
\hline Eutrophication, $\mathrm{g} \mathrm{PO}_{4}$-eq & 4.36 & 4.28 & 4.20 & 4.10 \\
\hline Acidification, $\mathrm{g} \mathrm{SO}_{2}$-eq & 7.74 & 7.95 & 8.15 & 8.36 \\
\hline
\end{tabular}

a Growing I, growing II, finishing I, and finishing II feeds were formulated based on animals 70-84, 91-105, 112-133, and 140-161 days of age, respectively, with 40, 60, 85, and $112.5 \mathrm{~kg}$ of body weight on average, respectively.

bSO-SO scenario: Soybean and corn produced in Southern Brazil.

${ }^{c}$ CW-SO scenario: Soybean produced in Central-West Brazil and corn produced in Southern Brazil.

${ }^{d} \mathrm{CW}$-CW scenario: Soybean and corn produced in Central-West Brazil.

TABLE 7 | Potential environmental impacts of control feeds ${ }^{\mathrm{a}}(1 \mathrm{~kg}$ at feed mill gate, formulated without $\beta$-mannanase) for broilers in different grain production scenarios.

\begin{tabular}{|c|c|c|c|c|c|}
\hline & \multicolumn{2}{|c|}{ Starter } & \multicolumn{2}{|c|}{ Growing } & \multirow[t]{2}{*}{ Finishing } \\
\hline & $\mathbf{I}$ & II & 1 & II & \\
\hline \multicolumn{6}{|l|}{ SO-SO scenario ${ }^{b}$} \\
\hline Climate change, $\mathrm{g} \mathrm{CO}_{2}$-eq & 816 & 877 & 910 & 857 & 848 \\
\hline Eutrophication, $\mathrm{g} \mathrm{PO}_{4}$-eq & 4.94 & 4.97 & 4.90 & 4.71 & 4.62 \\
\hline Acidification, $\mathrm{g} \mathrm{SO}_{2}$-eq & 5.96 & 6.13 & 6.56 & 7.17 & 7.50 \\
\hline \multicolumn{6}{|l|}{ CW-SO scenario ${ }^{C}$} \\
\hline Climate change, $\mathrm{g} \mathrm{CO}_{2}$-eq & 1,082 & 1,128 & 1,130 & 1,035 & 1,002 \\
\hline Eutrophication, $\mathrm{g} \mathrm{PO}_{4}$-eq & 4.86 & 4.89 & 4.83 & 4.66 & 4.58 \\
\hline Acidification, $\mathrm{g} \mathrm{SO}_{2}$-eq & 7.26 & 7.35 & 7.63 & 8.04 & 8.25 \\
\hline \multicolumn{6}{|l|}{ CW-CW scenario ${ }^{d}$} \\
\hline Climate change, g CO & 1,130 & 1,178 & 1,185 & 1,100 & 1,072 \\
\hline Eutrophication, $\mathrm{g} \mathrm{PO}_{4}$-eq & 4.90 & 4.94 & 4.88 & 4.72 & 4.64 \\
\hline Acidification, $\mathrm{g} \mathrm{SO}_{2}$-eq & 6.80 & 6.87 & 7.09 & 7.41 & 7.58 \\
\hline
\end{tabular}

a Starter I, starter II, growing I, growing II, and finishing feeds were formulated based on animals with 1-7, 8-21, 22-33, 34-42, and 43-46 days of age, respectively, and 0.14, $0.59,1.65,2.78$, and $3.48 \mathrm{~kg}$ of body weight, respectively.

${ }^{b}$ SO-SO scenario: Soybean and corn produced in Southern Brazil.

${ }^{c}$ CW-SO scenario: Soybean produced in Central-West Brazil and corn produced in Southern Brazil.

${ }^{d}$ CW-CW scenario: Soybean and corn produced in Central-West Brazil.

considering the inclusion of the enzyme and its energy matrix, there were some modifications in the ingredient use, which lead to changes in the potential environmental impact associated with 


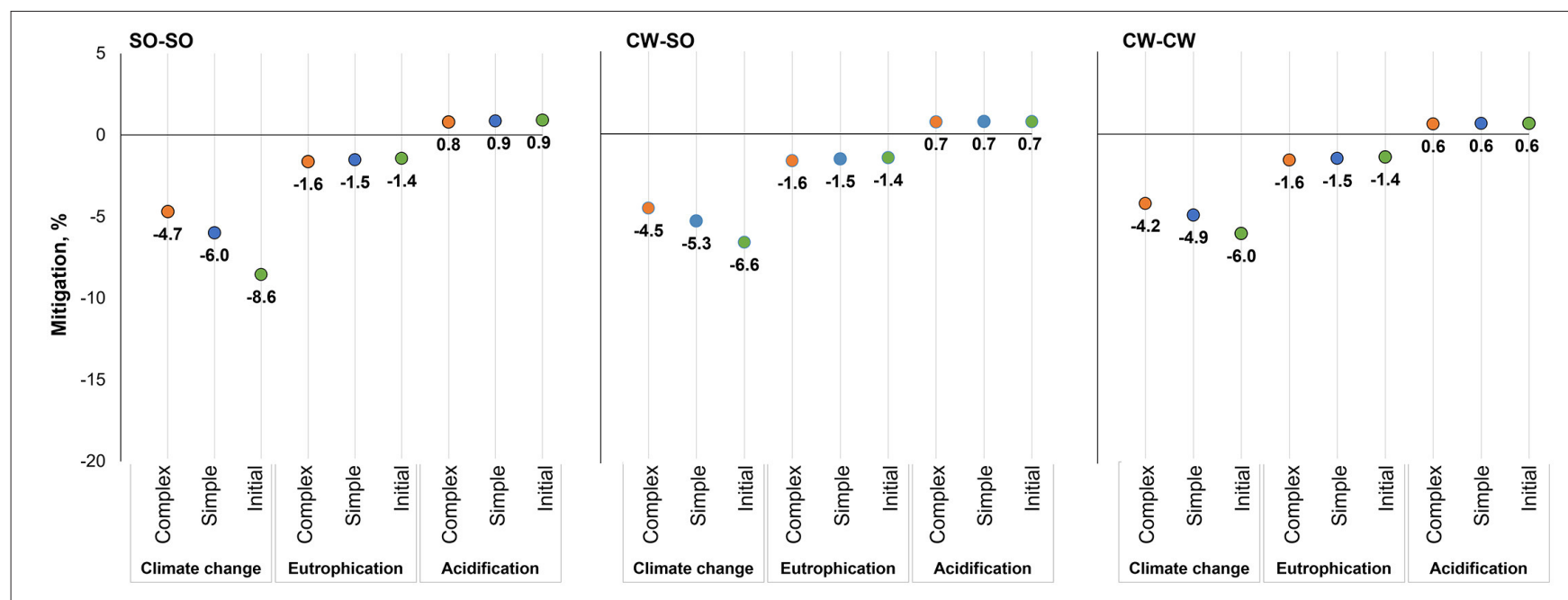

FIGURE 2 | Potential environmental impact mitigation associated with the production of piglet feeds, considering energy savings from an energy matrix of 90 kcal of $\mathrm{ME} / \mathrm{kg}$ of feed released by $\beta$-mannanase supplementation in different grain production scenarios; SO-SO, Soybean and corn produced in Southern Brazil; CW-SO, Soybean produced in Central-West Brazil and corn produced in Southern Brazil; CW-CW, Soybean and corn produced in Central-West Brazil.

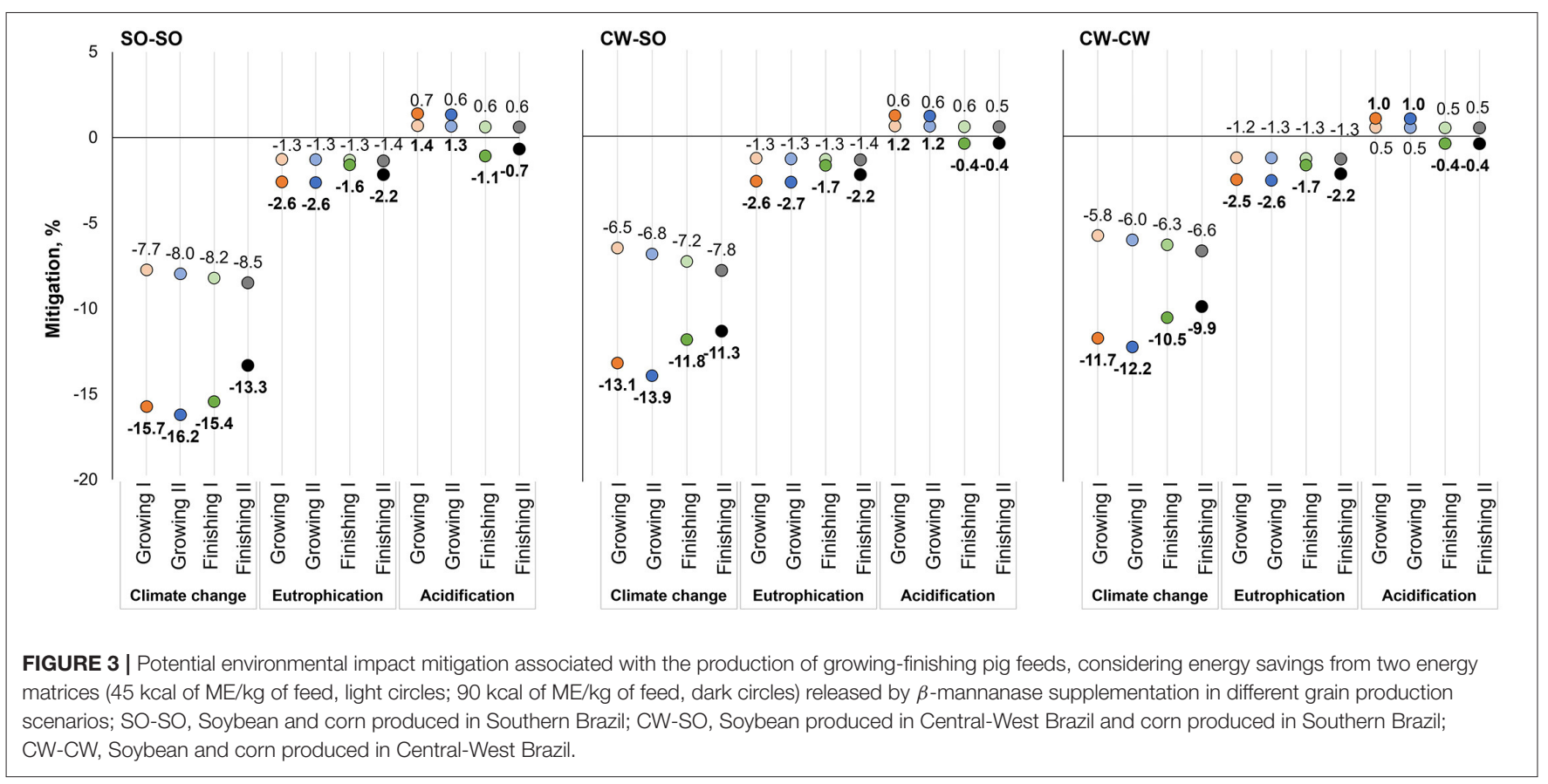

the same functional unit of feed production (Figures 2-4). The use of $\beta$-mannanase associated with an energy matrix of 90 $\mathrm{kcal}$ of $\mathrm{ME} / \mathrm{kg}$ for pre-starter diets leads to the mitigation of $59 \mathrm{~g}$ of $\mathrm{CO}_{2}$-eq per $\mathrm{kg}$ of produced feed, representing a greater percentage reduction in simple than complex diets. Using $\beta$ mannanase in growing-finishing pig feeds reduced the potential impact of climate change up to $16.2 \%$ when using an energy matrix of $90 \mathrm{kcal}$ of $\mathrm{ME} / \mathrm{kg}$ and up to $8.5 \%$ when considering $45 \mathrm{kcal}$ of ME/kg. The eutrophication impact of producing the same feeds was reduced up to $2.7 \%$ when using an energy matrix of $90 \mathrm{kcal}$ of $\mathrm{ME} / \mathrm{kg}$, while the reduction reached up to $1.4 \%$ when using an energy matrix of $45 \mathrm{kcal}$ of ME $/ \mathrm{kg}$. The climate change impact of producing feeds for broilers was reduced up to $5.6 \%$, while the eutrophication impact was reduced by up to $1.1 \%$.

The effect of using $\beta$-mannanase on the acidification impact was not consistent among feeds. Although mitigation on the potential acidification impact was observed in feeds for finishing pigs, the use of $\beta$-mannanase (and the consequent modifications in other ingredients inclusion) increased the acidification impact associated with most other pig feeds (even when formulating considering an 

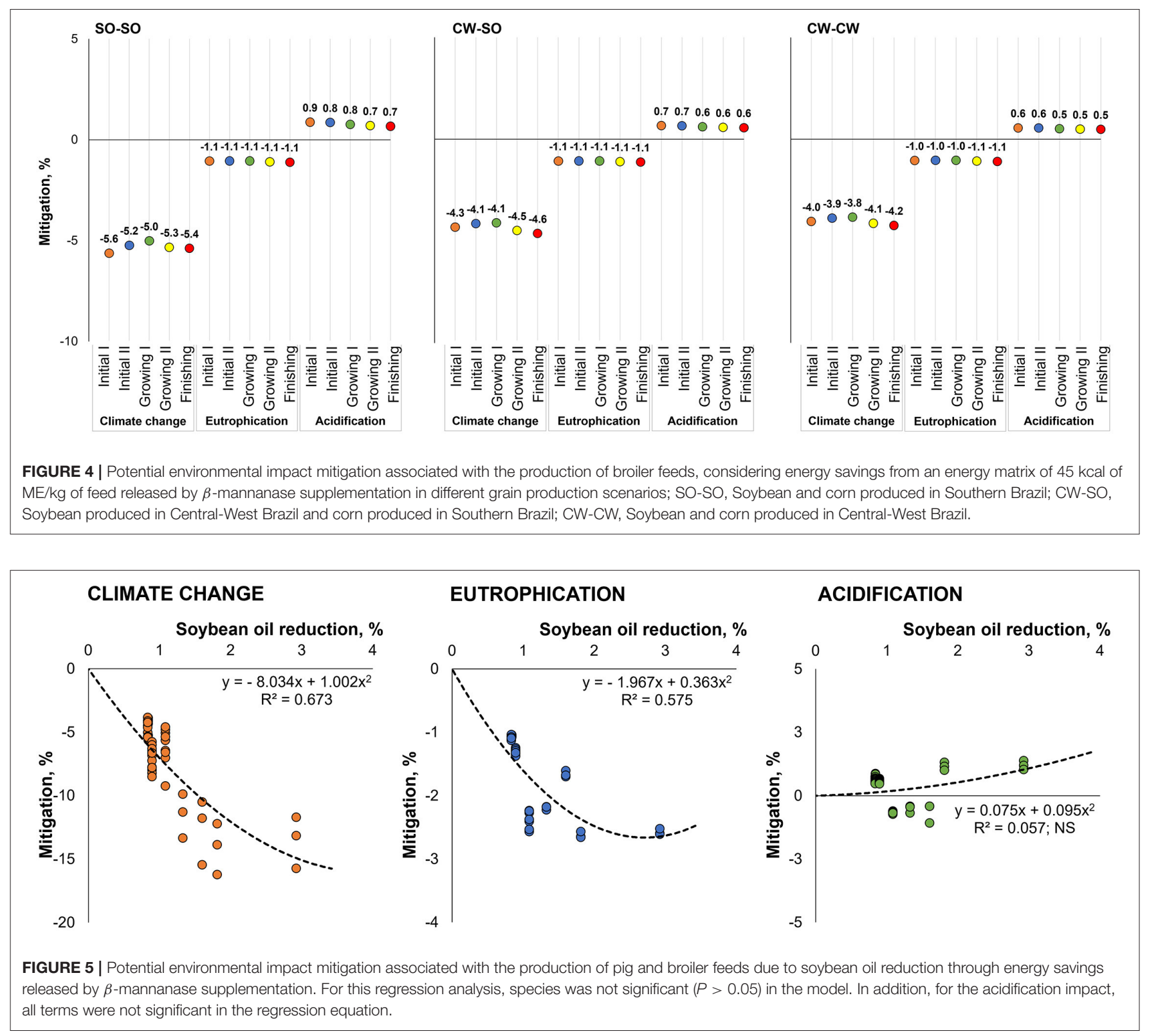

energy matrix of $90 \mathrm{kcal}$ of $\mathrm{ME} / \mathrm{kg}$ ) and with all broiler feeds evaluated.

The use of $\beta$-mannanase allowed a reduction in the amount of soybean oil in the feed formulas, which is associated with a high environmental impact. Consequently, the potential impacts of climate change and eutrophication were mitigated. A quadratic regression explained the association between soybean oil reduction in feed formulas (as a consequence of $\beta$-mannanase supplementation) and the mitigation of both climate change and eutrophication impacts (Figure 5).

The mitigation effect of $\beta$-mannanase supplementation is comparable between species when the total amount of feed used to raise a pig or a broiler is considered in the simulation (i.e., the feeding program, considering the feed used from hatch/weaning until slaughter, excluding breeding phases; Table 8). $\quad \beta$-mannanase supplementation produced greater changes on the potential impact of climate change (reduction of up to $4.7 \%$ in feeding programs for pigs and $5.2 \%$ in feeding programs for broilers) compared to the eutrophication $(-1.6 \%$ in pigs and $-1.1 \%$ in broiler). Changes in the acidification impact associated with $\beta$-mannanase supplementation are positive (i.e., increased environmental impact), however, lower than $1 \%$ in all studied scenarios. When simulating the impacts using another formulation strategy (Table 9), mitigation was higher: the potential impact of climate change was reduced up to $18 \%$, while eutrophication and acidification were mitigated by 6 and $4 \%$, respectively. However, it is hard to compare results since they originally used different ingredients and formulation methods. 
TABLE 8 | Changes in the environmental impacts associated with $\beta$-mannanase supplementation when the total amount of feed used to raise a pig or a broiler (from hatch/weaning until slaughter, excluding breeding phases) is considered in the simulation ${ }^{\mathrm{a}}$.

\begin{tabular}{|c|c|c|}
\hline & Pig & Broiler \\
\hline \multicolumn{3}{|l|}{ SO-SO scenario ${ }^{b}$} \\
\hline Climate change, $\mathrm{kg} \mathrm{CO}$-eq & $-11.14(-4.7 \%)$ & $-0.271(-5.2 \%)$ \\
\hline Eutrophication, $\mathrm{g} \mathrm{PO}_{4}$-eq & $-12.56(-1.6 \%)$ & $-0.308(-1.1 \%)$ \\
\hline Acidification, $\mathrm{g} \mathrm{SO}_{2}$-eq & +11.95 (+0.8\%) & $+0.297(+0.7 \%)$ \\
\hline \multicolumn{3}{|l|}{ CW-SO scenario ${ }^{C}$} \\
\hline Climate change, $\mathrm{kg} \mathrm{CO}$-eq & $-11.29(-4.5 \%)$ & $-0.276(-4.3 \%)$ \\
\hline Eutrophication, $\mathrm{g} \mathrm{PO}_{4}$-eq & $-12.51(-1.6 \%)$ & $-0.307(-1.1 \%)$ \\
\hline Acidification, $\mathrm{g} \mathrm{SO}_{2}$-eq & $+11.23(+0.7 \%)$ & $+0.277(+0.6 \%)$ \\
\hline \multicolumn{3}{|l|}{ CW-CW scenario ${ }^{d}$} \\
\hline Climate change, $\mathrm{kg} \mathrm{CO}$-eq & $-11.04(-4.2 \%)$ & $-0.270(-4.0 \%)$ \\
\hline Eutrophication, $\mathrm{g} \mathrm{PO}_{4}$-eq & $-12.29(-1.6 \%)$ & $-0.301(-1.1 \%)$ \\
\hline Acidification, $\mathrm{g} \mathrm{SO}_{2}$-eq & $+8.86(+0.6 \%)$ & $+0.219(+0.5 \%)$ \\
\hline
\end{tabular}

${ }^{a}$ Feed intake for each animal phase was estimated using the Brazilian Tables for Poultry and Swine (22). Values indicate the total amount mitigated/increased when $\beta$-mannanase is used in the formulations, followed by the percentage change compared to scenarios without $\beta$-mannanase supplementation.

bSO-SO scenario: Soybean and corn produced in Southern Brazil.

${ }^{c}$ CW-SO scenario: Soybean produced in Central-West Brazil and corn produced in Southern Brazil.

${ }^{d}$ CW-CW scenario: Soybean and corn produced in Central-West Brazil.

TABLE 9 | Potential environmental impacts of feeds (1 $\mathrm{kg}$ at feed mill gate) formulated for growing pigs based on the $150 \mathrm{kcal}$ digestible energy reduction per $\mathrm{kg}$ of feed, with $\beta$-mannanase supplemented diets compared to control diets.

\begin{tabular}{|c|c|c|c|}
\hline & \multicolumn{2}{|c|}{ Treatments $^{\mathrm{a}}$} & \multirow[t]{2}{*}{ Mitigation, \% } \\
\hline & Control & $\beta$-mannanase & \\
\hline \multicolumn{4}{|l|}{ SO-SO scenario ${ }^{b}$} \\
\hline Climate change, $\mathrm{g} \mathrm{CO}_{2}$-eq & 587.19 & 479.41 & -18 \\
\hline Eutrophication, $\mathrm{g} \mathrm{PO}_{4}$-eq & 4.27 & 3.99 & -6 \\
\hline Acidification, $\mathrm{g} \mathrm{SO}_{2}$-eq & 7.88 & 7.56 & -4 \\
\hline \multicolumn{4}{|l|}{ CW-SO scenario ${ }^{C}$} \\
\hline Climate change, $\mathrm{g} \mathrm{CO}_{2}$-eq & 717.01 & 596.31 & -17 \\
\hline Eutrophication, $\mathrm{g} \mathrm{PO}_{4}$-eq & 4.23 & 3.96 & -6 \\
\hline Acidification, $\mathrm{g} \mathrm{SO}_{2}$-eq & 8.42 & 8.13 & -4 \\
\hline \multicolumn{4}{|l|}{ CW-CW scenario ${ }^{d}$} \\
\hline Climate change, $\mathrm{g} \mathrm{CO}_{2}$-eq & 790.11 & 666.82 & -16 \\
\hline Eutrophication, $\mathrm{g} \mathrm{PO}_{4}$-eq & 4.29 & 4.02 & -6 \\
\hline Acidification, $\mathrm{g} \mathrm{SO}_{2}$-eq & 7.72 & 7.45 & -4 \\
\hline
\end{tabular}

${ }^{a}$ Control formula contains $3,400 \mathrm{kcal}$ of digestible energy and formula supplemented with $\beta$-mannanase, considering an energy matrix of $150 \mathrm{kcal}$ of digestible energy $/ \mathrm{kg}$ of feed. Treatments proved to have similar performance and digestibility (12).

bSO-SO scenario: Soybean and corn produced in Southern Brazil.

${ }^{c} \mathrm{CW}$-SO scenario: Soybean produced in Central-West Brazil and corn produced in Southern Brazil.

${ }^{d}$ CW-CW scenario: Soybean and corn produced in Central-West Brazil.

The simulation to estimate the minimum amount of energy matrix necessary to mitigate the environmental cost of producing and transporting the enzyme considered that soybean oil was replaced entirely by corn in the formulas to estimate the environmental cost of using $\beta$-mannanase in feeds for pigs and poultry, as the changes in soybean meal depend on the energy matrix used in the formulation (Figure 6). Considering that the inclusion of $\beta$-mannanase is $300 \mathrm{~g}$ per ton of feed and the functional unit of $1 \mathrm{~kg}$ of manufactured feed, the impact associated with the enzyme is $6 \mathrm{~g}$ of $\mathrm{CO}_{2}$-eq, $0.0151 \mathrm{~g}$ of $\mathrm{PO}_{4}$-eq, and $0.0262 \mathrm{~g}$ of $\mathrm{SO}_{2}$-eq (indicated by an $\mathrm{A}$ within each panel). When the soybean oil impact is estimated considering Ecoinvent references, the production of soybean oil $(1 \mathrm{~kg}$ at the feed mill gate) was associated with the emission of $6,008 \mathrm{~g}$ of $\mathrm{CO}_{2}$-eq, $9.71 \mathrm{~g}$ of $\mathrm{PO}_{4}$-eq, and $5.00 \mathrm{~g}$ of $\mathrm{SO}_{2}$-eq. The mitigation of climate change occurred at an energy matrix of $5.4 \mathrm{kcal}$ for pigs and $5.9 \mathrm{kcal}$ for broilers (indicated by a B within each panel), while eutrophication was mitigated at $17 \mathrm{kcal}$ for pigs and $18 \mathrm{kcal}$ for broilers. However, the mitigation may occur even with a lower energy matrix (indicated by $\mathrm{C}$ and $\mathrm{D}$ within each panel) if other references were used to characterize the environmental impacts of soybean oil. It is worth mentioning that, in real-life conditions, it is recommended to use a percentage of soybean oil to stimulate the feed's palatability and improve mixing conditions.

\section{DISCUSSION}

With regards to the environmental impacts of using $\beta$-mannanase in feeds, our results are similar to those obtained by Nielsen et al. (5) when describing the phytase production (1,900 $\mathrm{g}$ of $\mathrm{CO}_{2}$-eq, $2.20 \mathrm{~g}$ of $\mathrm{PO}_{4}$-eq, and $4.80 \mathrm{~g}$ of $\mathrm{SO}_{2}$-eq, $1 \mathrm{~kg}$ at the enzyme producer). On the other hand, for the environmental impacts of grain production, crop management practices and expansion rates varied among the Brazilian regions simulated in this study, and so did results. Alvarenga et al. (17) reported equivalent environmental impacts for broiler chicken diets produced in Brazil, but with a slighter lower climate change impact, especially for the CW-CW scenario. Cherubini et al. (25) also reported equivalent impacts in terms of carbon footprint when assessing diets for finishing pigs in Brazil. Both climate change and eutrophication impacts estimated in the current study were also comparable to those obtained by van der Werf et al. (26) and Mosnier et al. (19), who assessed finishing pig diets produced in France using Brazilian soybean. On the other hand, results concerning the use of $\beta$-mannanase on acidification were not consistent among feeds once the acidification impact was heavily associated with the feed formula being considered in the simulation. In other words, for some feeds, there was a slight increase in the acidification impact following $\beta$-mannanase supplementation; for other feeds, it was quite the opposite. For growing pig diets, the acidification impact was greater when considering the $90 \mathrm{kcal}$ of $\mathrm{ME} / \mathrm{kg}$ of feed matrix. However, for finishing pig diets, soybean oil was removed from the feed formula for this matrix, lowering its impact on acidification. The acidification impact varied with the corn/soybean proportion. Both climate change and eutrophication impacts are greater for soybean than corn. On the other hand, the acidification impact is greater for corn, especially the one from the Southern region. As this corn/soybean ratio varies from region to region, the same 

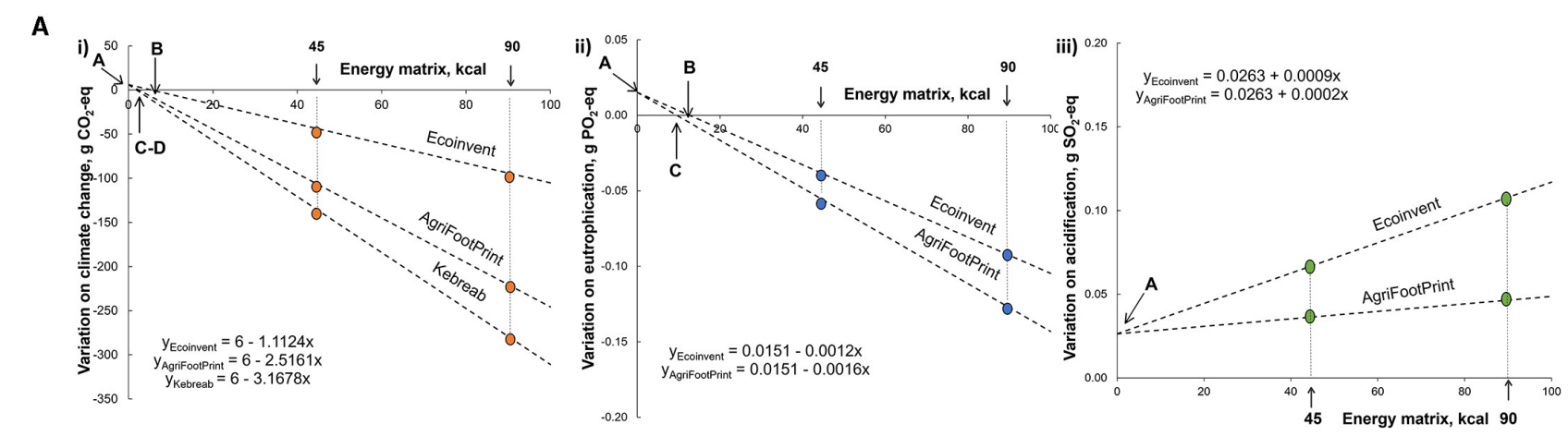

B
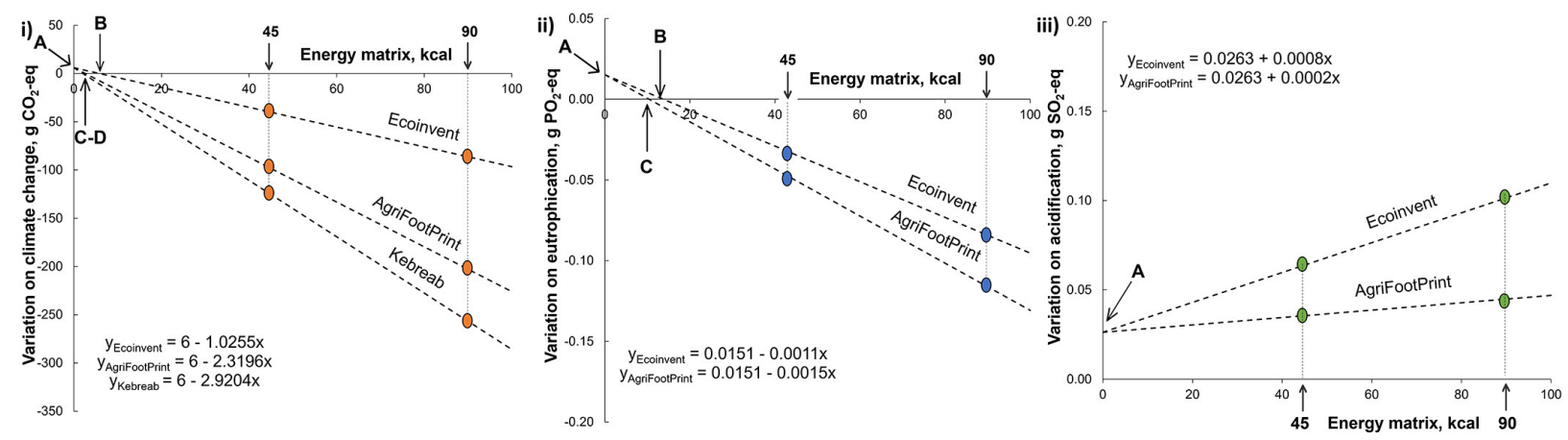

FIGURE 6 | Minimum energy matrix necessary to mitigate the environmental cost associated with $\beta$-mannanase supplementation in pig (A) and broiler (B) feeds. Within each panel, the letter A indicates the environmental cost of $\beta$-mannanase supplementation for $1 \mathrm{~kg}$ of feed, while letters $\mathrm{B}$ (Ecoinvent database v. 3.0, Swiss Center for Life Cycle Inventories, Dübendorf, Switzerland), C (AgriFootPrint v. 5.0, Blonk Consultants, Gouda, The Netherlands), and D [Kebreab et al. (24)] indicate the energy matrix able to mitigate this impact on climate change (i), eutrophication (ii), and acidification (iii) depending on the reference considered to account soybean oil production.

change (\%) in the formula ends up increasing or mitigating the overall acidification impact.

For growing-finishing pig feeds, the energy matrix of $\beta$ mannanase was chosen based on the most common values applied to the Brazilian industry (45 or $90 \mathrm{kcal}$ of $\mathrm{ME} / \mathrm{kg}$ of feed). For feeds that do not use exogenous enzymes other than $\beta$-mannanase, the saving of $90 \mathrm{kcal}$ of $\mathrm{ME} / \mathrm{kg}$ of feed provided by $\beta$-mannanase is commonly considered. On the other hand, for feeds that include a mix of enzymes, a $45 \mathrm{kcal}$ of $\mathrm{ME} / \mathrm{kg}$ of feed matrix is more appropriate. Broiler feeds under Brazilian feeding programs commonly include multiple exogenous enzymes when formulated. Therefore, we only considered a $45 \mathrm{kcal}$ of $\mathrm{ME} / \mathrm{kg}$ of feed matrix in our simulations for broilers. Despite the differences among the several enzyme supplementation strategies available for nutritionists, all simulated values are much higher than the minimum matrix necessary to mitigate the environmental impact associated with the enzyme incorporation in the formula (i.e., $5.4 \mathrm{kcal}$ of ME for pigs and $5.9 \mathrm{kcal}$ of $\mathrm{ME}$ for broilers to mitigate the climate change impact, or $17 \mathrm{kcal}$ of ME for pigs and $18 \mathrm{kcal}$ of ME for broilers considering the eutrophication impact). The use of an energy matrix of $45 \mathrm{kcal}$ of $\mathrm{ME} / \mathrm{kg}$ of feed associated with $\beta$-mannanase reduced by 0.90 and 0.84 percent points the inclusion of soybean oil in feed formulas for pigs and broilers, respectively. Considering the recent price conditions in Brazil, the space created in the formula by the reduction of oil use is occupied by corn. However, the average inclusion of corn in the feeds with $\beta$-mannanase increased by 0.99 and 0.95 percent points for pigs and broilers, respectively, compared to control diets. Corn variation was higher than the reduction in oil use because soybean meal inclusion was also reduced (on average, a reduction of 0.12 percent points). From an environmental standpoint, these variations are favorable as soybean meal and soybean oil are associated with a higher environmental impact than corn. Formulating feeds for pigs and poultry through liquid energy is a reality in some countries. However, this is not the case in Brazil and therefore it was not included in our analyses.

Overall, the greater environmental impact observed for soybean oil compared to corn is mainly because of the greater amount of resources needed to obtain this ingredient, such as land and fertilizers. The impact of soybean oil considered in this study was based on the Ecoinvent database (v. 3.0, Swiss Center for Life Cycle Inventories, Dübendorf, Switzerland), which is lower than other references for the same product. Simulating the production of $1 \mathrm{~kg}$ of feed, the changes in feed formula (average reduction of soybean oil and meal, and increasing corn use) caused by $\beta$-mannanase can prevent the emission of $55 \mathrm{~g}$ of $\mathrm{CO}_{2}$ eq and $0.11 \mathrm{~g}$ of $\mathrm{PO}_{4}$-eq. If values from AgriFootPrint (v. 5.0, 
Blonk Consultants, Gouda, The Netherlands) were considered, the mitigation is raised to $112 \mathrm{~g}$ of $\mathrm{CO}_{2}$-eq and $0.13 \mathrm{~g}$ of $\mathrm{PO}_{4}$-eq. If the impact estimated by Kebreab et al. (24) for Brazilian soybean oil would be considered, the mitigation associated with $\beta$ mannanase could reach $140 \mathrm{~g}$ of $\mathrm{CO}_{2}$-eq per $\mathrm{kg}$ of feed produced. These differences are mostly due to the grain production scenario considered in the database (Southern or Central-West origin).

Differences in the environmental impact of $\beta$-mannanase supplementation between pig and poultry feeding programs are mostly due to the ingredients included in diet formulations as each ingredient has it is own environmental impact. However, the pig and poultry sectors share some similarities not only from an organizational point of view but also from an environmental one. Pig and poultry production systems have been pointed out as large contributors to environmental impacts, such as climate change, eutrophication, and acidification $(3,27)$. Feeding both pigs and poultry requires tremendous amounts of feed resources, especially rich in protein and/or energy, with several studies indicating it as the most important source of environmental impact $(2,4)$. Novel feeding strategies are thus needed to tackle the challenges of these sectors. Our study has shown that $\beta$-mannanase supplementation can be considered as an ecofriendly feed strategy to reduce the environmental impacts of pig and poultry feeding programs. This was mostly because $\beta$ mannanase is a nutrient-sparing enzyme that breaks down $\beta$ mannans, leading to an increase in energy-use efficiency for both sectors.

\section{CONCLUSION}

$\beta$-mannanase supplementation reduced the amount of soybean oil in feed formulas, which is associated with high environmental impacts. Consequently, the potential impacts of climate change and eutrophication associated with producing feeds for pigs and broilers were substantially mitigated. These results suggest that $\beta$-mannanase supplementation is an eco-friendly feed strategy to reduce the environmental impacts of pig and poultry feeding programs. As feeding accounts for most of the environmental impacts associated with pig and poultry production, strategies

\section{REFERENCES}

1. Lovatto PA, Hauschild L, Hauptli L, Lehnen CR, Carvalho AD. Modelagem da ingestão, retenção e excreção de nitrogênio e fósforo pela suinocultura brasileira. Revista Brasileira de Zootecnia. (2005) 34:2348-54. doi: 10.1590/S1516-35982005000700022

2. McAuliffe GA, Chapman DV, Sage CL, A. thematic review of life cycle assessment (LCA) applied to pig production. Environ Impact Assess Rev. (2016) 56:12-22. doi: 10.1016/j.eiar.2015.08.008

3. Dourmad J-Y, Ryschawy J, Trousson T, Bonneau M, Gonzàlez J, Houwers $\mathrm{H}$, et al. Evaluating environmental impacts of contrasting pig farming systems with life cycle assessment. Animal. (2014) 8:2027-37. doi: 10.1017/S1751731114002134

4. Andretta I, Kipper M, Remus A, Orso C, Franceschi C. Environmental impacts of feeding crops to pigs and poultry. In: Galanakis C, editor. Environmental Impact of Agro-Food Industry and Food Consumption. Cambridge: Academic Press (2021). p. 59-79. doi: 10.1016/B978-0-12-821363-6.00001-1 such as $\beta$-mannanase supplementation that mitigate these impacts are desired. This feeding strategy improves the overall sustainability of pig and poultry production systems by increasing energy-use efficiency. It is worth mentioning that the $\beta$-mannanase supplementation described in this study is only one way to address the environmental impacts of feeding pigs and broilers. Several other approaches and techniques must be considered in an integrated way toward more sustainable animal systems.

\section{DATA AVAILABILITY STATEMENT}

The raw data supporting the conclusions of this article will be made available by the authors, without undue reservation.

\section{AUTHOR CONTRIBUTIONS}

$\mathrm{FH}$ and IA assisted with data analysis, interpreted results, prepared tables and figures, and drafted the manuscript. MK assisted with data analysis, interpretation and discussion of results. GG, AR, JV, and M-PL-M were involved in the interpretation and discussion of results. All authors have contributed to this research and approved the final version of the manuscript.

\section{FUNDING}

The authors would like to thank Coordenação de Aperfeiçoamento de Pessoal de Nível Superior (CAPES) and Conselho Nacional de Desenvolvimento Científico e Tecnológico $(\mathrm{CNPq})$ from Brazil for funding this research, and the in-kind support from Elanco Animal Health for sharing the $\beta$-mannanase Hemicell ${ }^{\mathrm{TM}} H T$ production inventory.

\section{ACKNOWLEDGMENTS}

The authors appreciate the in-kind support of Elanco Animal Health for this research by providing data of all procedures concerning the production of $\beta$-mannanase.

5. Nielsen PH, Oxenbøll KM, Wenzel H. Cradle-to-gate environmental assessment of enzyme products produced industrially in Denmark by Novozymes A/S. Int J Life Cycle Assessment. (2016) 12:432. doi: 10.1007/s11367-006-2651-4

6. Jegannathan KR, Nielsen PH. Environmental assessment of enzyme use in industrial production - a literature review. J Cleaner Production, Elsevier. (2013) 42:228-40. doi: 10.1016/j.jclepro.2012.11.005

7. Kim JS, Ingale SL, Lee SH, Kim HM, Kim JS, Lee JH, et al. Effects of energy levels of diet and $\beta$-mannanase supplementation on growth performance, apparent total tract digestibility and blood metabolites in growing pigs. Anim Feed Sci Technol. (2013) 186:64-70. doi: 10.1016/j.anifeedsci.2013.08.008

8. Shastak Y, Ader P, Feuerstein D, Ruehle R, Matuschek M. BMannan and mannanase in poultry nutrition. World's Poultry Science Journal. (2015) 71:161-74. doi: 10.1017/S00439339150 00136

9. Ferreira HC, Hannas MI, Albino LFT, Rostagno HS, Neme R, Faria BD, Xavier MLJr, Rennó LN. Effect of the addition of $\beta$-mannanase on the performance, metabolizable energy, amino acid digestibility coefficients, and 
immune functions of broilers fed different nutritional levels. Poultry Sci. (2016) 1848-57 doi: 10.3382/ps/pew076

10. Kipper M, Andretta I, Quadros VR, Schroeder B, Pires PGS, Franceschina CS, et al. Performance responses of broilers and pigs fed diets with $\beta$-mannanase. Revista Brasileira de Zootecnia. (2020) 49:e20180177. doi: 10.37496/rbz4920180177

11. Guinée JB. Handbook on life cycle assessment: operational guide to the ISO standards. Amsterdam, Springer Netherlands: Int J Life Cycle Assess (2002). p. 692. doi: 10.1007/BF02978897

12. Lv JN, Chen YQ, Guo XJ, Piao XS, Cao YH, Dong B. Effect of supplementation of $\beta$-mannanase in corn-soybean meal diets on performance and nutrient digestibility in growing pigs. Asian-Australas J Anim Sci. (2013) 26:57987. doi: 10.5713/ajas.2012.12612

13. Gilpin GS, Andrae AS. Comparative attributional life cycle assessment of European cellulase enzyme production for use in second-generation lignocellulosic bioethanol production. Int J Life Cycel Assess. (2017) 22:103453. doi: 10.1007/s11367-016-1208-4

14. Andretta I, Hauschild L, Kipper M, Pires PGS, Pomar C. Environmental impacts of precision feeding programs applied in pig production. Animal. (2018) 12:1990-8. doi: 10.1017/S1751731117003159

15. Instituto Brasileiro de Geografia e Estatística. Sistema IBGE de recuperação automática - SIDRA: Produção Agrícola Municipal (2020). Available online at: https://sidra.ibge.gov.br/pesquisa/pam/tabelas (accessed April 12, 2021).

16. Alvarenga, RAF. Avaliação de métodos de AICV: um estudo de caso de quatro cenários de ração para frangos de corte. [dissertation/master's thesis]. Florianópolis (SC): Universidade Federal de Santa Catarina, Brazil (2010).

17. Alvarenga RAF, Silva Júnior VP, Soares SR. Comparison of the ecological footprint and a life cycle impact assessment method for a case study on Brazilian broiler feed production. J Clean Prod. (2012) 28:2532. doi: 10.1016/j.jclepro.2011.06.023

18. Prudêncio da. Silva V, van der Werf HMG, Spies A, Soares SR. Variability in environmental impacts of Brazilian soybean according to crop production and transport scenarios. J Environ Managem. (2010) 91:18319. doi: 10.1016/j.jenvman.2010.04.001

19. Mosnier E, van der Werf HMG, Boissy J, Dourmad JY. Evaluation of the environmental implications of the incorporation of feed-use amino acids in the manufacturing of pig and broiler feeds using Life Cycle Assessment. Animal. (2011) 5:1972-83. doi: 10.1017/S1751731111001078

20. van Zeist WJ, Marinussen M, Broekema R, Groen E, Kool A, Dolman M, et al. LCI data for the calculation tool Feedprint for greenhouse gas emissions of feed production and utilization: Crushing industry. Gouda, the Netherlands: Blonk Consultants. (2012).

21. van Zeist WJ, Marinussen M, Broekema R, Groen E, Kool A, Dolman M, Blonk H. LCI data for the calculation tool Feedprint for greenhouse gas emissions of feed production and utilization: Dry milling industry. Gouda, the Netherlands: Blonk Consultants. (2012).
22. Rostagno HS, Albino LFT, Donzele JL, Gomes PC, Oliveira RF, Lopes DC, et al. Brazilian tables for poultry and swine: composition of feedstuffs and nutritional requirements. Viçosa: Universidade Federal de Viçosa (2017). p.482.

23. Minitab 20.2.0 Statistical Software (2021). [Computer software]. State College, PA: Minitab, Inc. Available online at: www.minitab.com

24. Kebreab E, Liedke A, Caro D, Deimling S, Binder M, Finkbeiner M. Environmental impact of using specialty feed ingredients in swine and poultry production: A life cycle assessment. J Anim Sci. (2016) 94:266481. doi: $10.2527 /$ jas.2015-9036

25. Cherubini E, Zanghelini GM, Tavares JMR, Belettini F, Soares SR. The finishing stage in swine production: influences of feed composition on carbon footprint. Environ Dev Sustain. (2015) 17:1313-28. doi: 10.1007/s10668-014-9607-9

26. van der Werf HMG, Petit J, Sanders J. The environmental impacts of the production of concentrated feed: the case of pig feed in Bretagne. Agric Syst. (2005) 83:153-77. doi: 10.1016/j.agsy.2004. 03.005

27. Cappelaere L, Le Cour Grandmaison J, Martin N, Lambert W. Amino acid supplementation to reduce environmental impacts of broiler and pig production: a review. Front Vet Sci. (2021) 8:689259. doi: $10.3389 /$ fvets.2021.689259

Conflict of Interest: The authors declare that this study received in-kind support from Elanco Animal Health, IN, United States, which shared the $\beta$-mannanase Hemicell $^{\mathrm{TM}} H T$ production inventory. In addition, MK and JV are employed by the company Elanco Animal Health.

The remaining authors declare that the research was conducted in the absence of any commercial or financial relationships that could be perceived as a potential conflict of interest.

Publisher's Note: All claims expressed in this article are solely those of the authors and do not necessarily represent those of their affiliated organizations, or those of the publisher, the editors and the reviewers. Any product that may be evaluated in this article, or claim that may be made by its manufacturer, is not guaranteed or endorsed by the publisher.

Copyright (c) 2021 Hickmann, Andretta, Létourneau-Montminy, Remus, Galli, Vittori and Kipper. This is an open-access article distributed under the terms of the Creative Commons Attribution License (CC BY). The use, distribution or reproduction in other forums is permitted, provided the original author(s) and the copyright owner(s) are credited and that the original publication in this journal is cited, in accordance with accepted academic practice. No use, distribution or reproduction is permitted which does not comply with these terms. 